\title{
URBAN AND PERI-URBAN FORESTRY IN A DEVELOPMENT CONTEXT-STRATEGY AND IMPLEMENTATION
}

\author{
by Cecil C. Konijnendijk1, Syaka Sadio², Thomas B. Randrup', \\ and Jasper Schipperijn'
}

\begin{abstract}
Sustainable urban development requires providing a healthy and sustainable living environment with basic services for all. A healthy and multifunctional urban green structure is one of the basic services to provide. Urban and peri-urban forestry (UPF), focusing on the tree-dominated part of urban and periurban greenspace, is a strategic, integrative, interdisciplinary, and participatory approach. Its goal is to sustainably develop the multiple benefits of forests and trees in urban environments. Recently, UPF has found broad following across the world, but its potential for cities and towns in developing countries is unrealized. The Food and Agriculture Organization (FAO) of the United Nations has developed a mid-term strategy for promoting and developing UPF as a component of sustainable urban development, with emphasis on developing countries. This paper introduces this strategy, which aims at raising awareness, developing state of art, generating new technology and knowledge, strengthening institutions and policy, disseminating information and knowledge, and enhancing sustainable UPF. Examples of successful UPF programs from both the developing and developed world are presented.

Key Words. Urban and peri-urban forestry; sustainable development; urbanization; developing countries; Food and Agriculture Organization.
\end{abstract}

\section{URBANIZING SOCIETY: CHALLENGES AND NEEDS}

Some people love cities; others hate them. While Henry David Thoreau considered cities to be places where "millions of people are feeling lonely together" (cited by Ponting 1990), others have praised cities as centers of innovation and learning, transmitting accumulated knowledge on which future achievements can be built (Girardet 1993). Whether one likes cities or not, the reality is that the majority of the world's population now lives in them and that further urbanization cannot be halted. By 2030, 60\% of all people are expected to reside in cities and towns (Töpfer 2001) (Figure 1). Urban areas grow three times faster than their rural counterparts (Palijon 2002; WRI 2004). Urbanization is no longer an industrialized-world phenomenon. Urban areas in developing countries will account for nearly $90 \%$ of the projected world population increase between 1995 and 2030. Soon more than half of the Asian and African populations will live in urban areas, while this share will be between $75 \%$ and $85 \%$ for Central and South America (FAO 2002; WRI 2004)

Ongoing urbanization has brought about a wide range of challenges across the globe, and not only in terms of population growth. In the United States, for example, metropolitan areas tripled in size between 1950 and 1990 (Dwyer et al. 2000). More land is needed for urban areas to provide inputs and outputs of resources and energy, with a detrimental effect on forests and other green areas. During the early 1990s, more than a quarter of greenspaces in Asia were expected to be lost within two decades due to continued urbanization and suburbanization (Kuchelmeister and Braatz 1993).

Especially in the developing world, where most emerging mega-cities are located, managing and catering for urban populations will be one of the main challenges of our time. The influx of rural populations will not stop. Continuing urbanization in the developing world has led to major problems in terms of hunger; poverty; inadequate shelter; social segregation; unemployment; pollution of water, soil, and atmosphere; and so forth. Those responsible for manag-

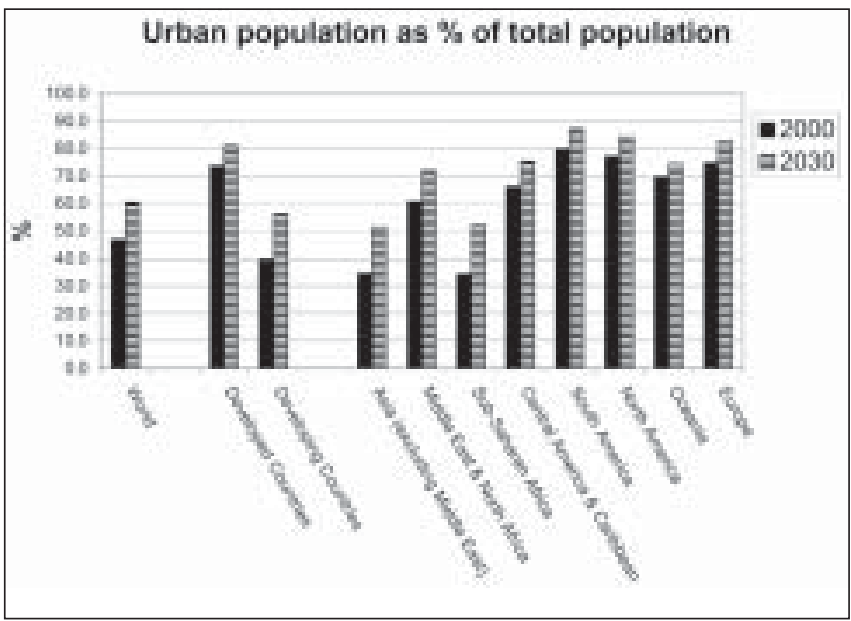

Figure 1. Urban population as percentage of total population for 2000 and predicted for 2030. Source: Population Division of Economic and Social Affairs of the United Nations Secretariat (1998) and the World Resources Institute (2004). 
ing cities are under tremendous pressure to develop strategies for alleviating poverty and sustaining urban livelihoods.

This paper argues that the development of multifunctional urban green structures can be an important contributor to sustainable urban development in terms of improving the quality of life and environment for current urban populations, without endangering the opportunities of future generations. In the developing world, green structures have an important role to play in poverty alleviation and provision of livelihoods. The Food and Agriculture Organization (FAO) of the United Nations has acknowledged its urban mandate and has developed a new program for promoting urban and peri-urban forestry, in particular in the developing countries.

\section{URBAN GREEN FOR SUSTAINABLE CITIES}

As described, problems concerning urbanization are very significant, especially in the developing world. Basic concerns such as the provision of food and housing, sanitation, and employment are to be prioritized, so why focus on green areas? Experiences and research during recent years have shown that urban green structures are more than just "icing on the cake." Far from being luxury goods, they deliver a range of goods and services to justifiably include them as part of the basic urban infrastructure.

\section{Economic and Livelihood Values of Urban Green}

Organizations such as FAO are very much concerned with alleviating poverty and improving food security. Agriculture production in or near urban areas, also called urban agriculture, should not be underestimated in this respect. Many countries have a long tradition of urban dwellers supplementing their diet and/or economy with local agricultural produce, and thus providing urban employment as well. Timber and other wood products are also very important in urban areas; large parts of the urban population of Africa, for example, are still heavily dependent on fuel wood (Kuchelmeister 1998). Systematic planting of street trees for timber production is widely practiced in China and Malaysia (Webb 1999). Timber from urban trees may provide construction material for housing and other buildings. Urban green areas also provide nonwood forest products such as mushrooms, berries, medicinal herbs, rattan, and so forth. Focus in the Western world has been on additional economic values such as green areas contributing to more attractive cities for people to work, live, and relax. Studies in Denmark and Finland, for example, have shown the positive impact of nearby forests and green on house prices (Tyrväinen 1999; Anthon and Thorsen 2001).

\section{Environmental and Biodiversity Values of Urban Green}

Trees and other vegetation intercept particles and gaseous pollutants (McPherson et al. 1997; Harris et al. 1999).
Moreover, they act as carbon sinks that help mitigate global warming (McPherson and Simpson 1999). Important in both the developed and developing world is the role urban vegetation plays regarding water. Trees reduce stormwater runoff and can assist with processing wastewater, for example, where other wastewater facilities are insufficient (e.g., El Lakany 1999). Many cities have established and conserved forests for protecting their drinking water resources (Konijnendijk 1999). Urban green protects soils and moderates harsh urban climates by cooling the air, reducing wind speeds, and by shading. In arid regions, forest shelterbelts around cities help combat desertification and dust storms, as the examples of Burkina Faso (Kambou 1992) and China (Lu and Wang 2003) show. The level of biodiversity of urban green areas is often surprisingly high, representing nature close to where people live. Cities such as Kuala Lumpur, Rio de Janeiro, and Singapore (Chin and Corlett 1986; El Lakany 1999; Webb 1999) still have tracts of tropical rainforest within their boundaries. In Europe, national parks are found at the gates of large cities such as Warsaw, Moscow, and Vienna (Konijnendijk 1999).

\section{Social and Cultural Values of Urban Green}

The recreational values of forests, parks, gardens, and other urban green areas are especially well documented in the Western world. Urban woodlands in Europe attract as many as several thousands of visits per hectare per year (Konijnendijk 1999). Because people tend to prefer outdoor recreational areas close to their homes, urban green areas are the most popular outdoor recreational areas. Recently, the health impacts of urban green have also been studied (e.g., Grahn and Stigsdotter 2003). Urban green can have a positive impact on physical and mental health, for example, by providing settings for physical exercise, reducing ultraviolet radiation and air pollution, and reducing stress. By being actively involved in tree planting and management, local communities can be strengthened (e.g., Burch and Grove 1993; Kuo 2003). In many developing countries, trees often have cultural and spiritual values (e.g., Seeland, in press) that could assist new urban dwellers in finding their place in cities and towns.

\section{URBAN AND PERI-URBAN FORESTRY: AN INTEGRATIVE AND STRATEGIC APPROACH}

Innovative concepts such as urban agriculture, urban greening, and urban ecology, as well as social and community forestry, all reflect the desire for innovative ways of managing natural resources. Approaches are needed to extend beyond traditional boundaries, involving a wide range of disciplines as well as stakeholders. In the case of urban green, they should recognize the multiple values provided, as well as the role these areas can play in sustainable development. The concept of "urban and peri-urban forestry" (UPF) is particu- 
larly promising approach to urban greenspace planning and management. It focuses on what are perhaps the main elements of urban green structures: forests and other treedominated vegetation in and around urban centers.

Miller (1997) defined UPF as "an integrated, citywide approach to the planting, care, and management of trees in the city to secure multiple environmental and social benefits for urban dwellers." Grey and Deneke (1986) provided a more elaborate definition: "Urban and periurban forestry is defined as the planned, integrated, and systematic approach to the management of trees in urban and peri-urban areas for their contribution to the physiological, sociological, and economic well-being of urban society. Urban forestry is multifaceted; it deals with woodlands, groups of trees, and individual trees where dense conglomerations of people live, involves a wide variety of habitats (streets, parks, derelict corners, etc), and is concerned with a great range of benefits and problems."

Within the concept of UPF, the mentioning of "periurban" stresses the inclusion of tree resources outside-but close to-urban areas, because these are major contributors in terms of goods and services to urban societies. The scope of urban forestry is summarized in Figure 2.

The concept of UPF builds on a history of more than 35 years and has its roots in North America. It has gradually gained broad following among scientists and practitioners, although the concept is still under scrutiny for adaptation to local conditions. The strengths of the concept of UPF include being

- integrative, incorporating different elements of urban green structures into a whole (the "urban forest");

- strategic, aimed at developing longer-term policies and plans for urban tree resources, connecting to different sectors, agendas, and programs;

- interdisciplinary, involving experts from natural as well as social sciences;

- participatory, aimed at developing partnerships between all stakeholders; and

- aimed at multiple benefits, stressing the economic, environmental, and sociocultural goods and services urban forests can provide.

UPF research, development, and implementation have become firmly established in North America and more recently in Europe. Other parts of the world, such as Asia, have also shown interest (Palijon 2002). As we will see in the next sections, however, the full potential of UPF has yet to be realized in the developing countries.

\section{A STRATEGY FOR DEVELOPING URBAN AND PERI-URBAN FORESTRY}

Lack of information and strategic, coordinated action has hampered implementation of UPF in the developing world (El Lakany 1999; FAO 2002). Therefore, FAO is promoting UPF in the developing world. Initial activities carried out during the 1990s included preparation of country reports, as well as other dissemination activities.

In 2002, the Forest Resources Division of FAO, through its Forest Research, Conservation and Education Service (FORC), released a midterm plan (2002-2007) for UPF. A strategic framework for this plan was developed jointly with the Danish Centre for Forest, Landscape and Planning, which heads the European Urban Forestry Research and Information Centre (EUFORIC).
Figure 2. The urban/peri-urban/rural forestry matrix (adapted from Konijnendijk and Randrup 2002, FAO 2002). The gray-shaded area represents the domain of UPF. 
The strategic framework is based on a review of existing UPF activities and needs in different parts of the world, with emphasis on the needs of developing countries. Issues in developing countries are different from those in developed countries. For example, alleviating poverty, providing livelihoods, and environmental services such as wastewater handling and combating desertification are pressing issues in the developing world, but less so in the Western world.

A summary of the strategic framework and actions to be taken, initially during the 2002-2007 period, is provided in Table 1. Raising awareness about the importance of UPF with key actors is an important component of the new strategy. To get a better overview of the status of UPF, stateof-art assessments are required. Based on these assessments, new technologies and knowledge can be developed. These activities will support the required institutional and policy strengthening. Experiences in North America and Europe have shown that much can be gained from good dissemination and sharing information through networks.

\section{EXAMPLES OF SUCCESSFUL PROGRAMS}

Fortunately, the strategy described above does not have to start from scratch. Relevant experiences and good practices have already been developed in different countries, regions, and cities, and even at the international level, although many of the experiences so far come from the industrialized world. Some of these efforts are discussed here.

\section{Raising Awareness}

UPF awareness increased in the United States during the 1970s, when environmental issues became paramount and nongovernmental organizations (NGOs) such as American Forests began to effectively lobby Congress for funding. A broad-based partnership was built based on a strategic approach to urban tree planting and management for generating multiple benefits. NGO awareness-raising led to strong links among research, policy, and implementation of UPF in the United States (Johnston 1996). The National Urban Forestry Unit (NUFU), an independent organization, has provided assistance to a large number of local and regional urban forestry initiatives in the United Kingdom (Konijnendijk 1999). The role of high-level politicians in awareness raising is important and is exemplified by the impact of U.S. President George H.W. Bush (with his America The Beautiful Program) and Chairman Mao Zedong in China (Johnston 1996; Palijon 2002). Eighty thousand residents of Puerto Princessa City in the Philippines were made aware of the benefits of UPF through their involvement in a massive reforestation project in their city (Palijon 2002).

Table 1. Brief summary of the Food and Agriculture Organization's mid-term plan for urban and peri-urban forestry.

\begin{tabular}{ll}
\hline Strategies & Actions \\
\hline Raising awareness & Strengthen awareness of urbanization and UPF issues across the world. \\
& Strengthen awareness and role of UPF within FAO. \\
Establish UPF dimensions as formal development policy strategy within FAO.
\end{tabular}

State of art assessment

New technology and knowledge generation

Institutional capacity and policy strengthening

Information sharing and dissemination

Sustainable development of UPF
Assess good practice within UPF.

Assess relevant past and present activities within FAO.

Undertake new case studies and projects aimed at developing good practice within UPF.

Develop strong FAO UPF program aimed at transferring new knowledge and technologies within UPF, with emphasis on the needs of developing countries.

Review national legal and policy framework.

Recommend strategies, guidelines, and measures for the promotion of UPF in urban and peri-urban areas.

Establish UPF dimensions as formal development policy strategy within FAO.

Establish North-South and South-South networks of UPF experts and stakeholders. Prepare UPF information dissemination system for FAO.

Improve information sharing system through establishment of network of knowledge and network for people (networks of excellence) and turn FAO into the main provider of information on UPF for developing countries.

Develop and adopt a participatory approach for UPF programs/projects development; identify key issues and needs of the countries and human development challenges, with focus on poverty alleviation in developing countries. 


\section{State-of-Art Assessment}

Before developing innovative approaches and tools, an assessment of the status and past experiences concerning UPF would be beneficial. Unfortunately, comparative assessments of UPF resources at a level higher than the city or town are rare. An exception has been the national urban forest resource assessment carried out in the United States (Dwyer et al. 2000). The study showed that about one quarter of all trees in the country are located in metropolitan areas and that their multiple values are considerable. FAO commissioned a series of UPF case studies in Egypt (Cairo), Ecuador (Quito), Brazil (Rio de Janeiro), Iran (Tehran), Senegal (Dakar), Mauritania (Nouakchott), Burkina Faso (Ouagadougou), Niger (Niamey), and Ethiopia (Addis Ababa) (El Lakany 1999), including a comparative study in Hong Kong, Kuala Lumpur, and Singapore (Webb 1999). These case studies showed the importance of UPF initiatives for urban development and compiled expertise for cities, which are at earlier stages in the development of their urban forestry programs. Assessments of research activities and higher education on urban forests and trees were made by the European Unionfinanced Cooperation in the field of Scientific and Technical Research (COST) Action E12 Urban Forests and Trees. In the developing world, research and development networking has so far been limited, although some recent efforts have been undertaken within the framework of the International Union of Forest Research Organizations (IUFRO).

\section{New Technology and Knowledge Generation}

The USDA Forest Service has generated extensive new knowledge on UPF and its benefits through its special urban forestry research centers. Based on their work, American Forests developed a software program (CITYgreen) that can assist local communities with assessing the value of their UPF resource (i.e., in terms of environmental functions) (Kollin 2002). The European Commission has financed several UPF research and development projects. In one project, called NeighbourWoods, partners from seven European countries develop new tools for the planning and design of urban woodlands (Konijnendijk et al. 2002).

\section{Institutional Capacity and Policy Strengthening}

South Africa is facing many problems related to rapid urbanization, complicated by its apartheid history. Problems relate, for example, to land, water, housing, and unemployment. One result is the lack of green areas in the former black townships. With support from Danish partners, the NGO Food and Trees for Africa is developing ways to integrate UPF into urban planning (Nilsson et al. 2003). Singapore has strongly institutionalized urban greenspace planning and management. It has developed a proposal for an island-wide park connector network (Yuen
1997, cited by Palijon 2002). The government of Ethiopia is attempting to stop degradation of plantations in Addis Ababa through a new policy stimulating private ownership (FAO 2002). The 1994 Tokyo Metropolitan Plan consists of comprehensive, systematic policies with regard to urban green areas and bodies of water in Tokyo (Tokyo Metropolitan Government 1998, cited by Kuchelmeister 1998). In the Philippines, a national policy exists that requires residential, commercial, and industrial estates to allocate at least $30 \%$ of the gross area as open space for parks, playgrounds, and recreational use (Palijon 2001).

\section{Information Sharing and Dissemination}

Networking among researchers, policy makers, practitioners, and other stakeholders is crucial in the newly emerging field of urban forestry. During recent years, some good examples of networking have emerged. The earlier-mentioned COST Action E12 placed UPF on the European research map through its network of about 100 experts from 22 European countries. The Action ran 5 years, during which several seminars, pilot studies, reviews, and other activities were organized (Nilsson and Konijnendijk 2002). IUFRO has facilitated UPF networking through its urban forestry working party. It also supported the European Forum on Urban Forestry, an annual meeting for European urban forestry practitioners to exchange ideas and experiences (Krott and Nilsson 1998). FAO has also played a major role through its publications, a concept paper on UPF (Carter 1994), and an annotated bibliography of urban forestry in the developing countries (FAO 1995). A special UPF issue of Unasylva (1993) is still frequently cited in literature. In 1997, the World Forestry Congress (WFC) included a subplenary session on UPF, and the topic was also on the agenda at the 2003 WFC. Information about UPF is also disseminated via organizations such as the Resource Centre for Urban Agriculture and Forestry (RUAF) and the European Urban Forestry Research and Information Centre (EUFORIC). Finally, "twinning" cooperation between countries provides another networking and information sharing tool. Malaysia and Denmark started a sustainable forest management program in 2003, with a component aimed at the advancement of UPF in both countries.

\section{Sustainable Development of UPF}

Sustainable development of UPF and the promotion of its contribution to sustainable development at large require a bold and strategic approach. UPF needs to be linked to a broad range of issues and agendas. In England, the government has developed a forestry strategy in which urban and peri-urban areas are the focus. Through its Community Forests program, UPF objectives are implemented. The Community Forests program uses the planting and management of forests and trees as vehicles for social, economic, 
and environmental regeneration of 12 large urban agglomerations in the country (Konijnendijk 1999). Hyderabad, Pakistan, is rapidly growing due to the boom in its hightech industry. To maintain an attractive and liveable city, local authorities set up an extensive greening program. Keeping the city competitive by keeping it attractive is a major objective (Zwingle 2002).

\section{THE ROAD AHEAD}

The examples presented are but a glimpse of the huge potential of UPF, especially in developing countries. They provide inspiration to the efforts by FAO and other organizations to promote the contribution of forests and trees to livelihoods in urban areas. By implementing the discussed framework during the initial period (2002-2007), FAO aims to develop capacities in urban and peri-urban forestry, especially in the developing world. As a next step, enhanced capacities and knowledge will assist with the development and implementation of national and local UPF programs aimed at contributing to urban livelihoods.

The concept of UPF promotes inclusiveness by involving experts, policy makers, and stakeholders from all walks of life. The need to join forces with other initiatives aimed at sustainable urban development is therefore crucial. Within FAO, for example, the Committee on Urban Agriculture confirmed the organization's role in urban agriculture and an interdepartmental working group, Food For Cities, was established. The Forest Policy and Institutions branch and its long-running community forestry program are other possible allies. Community forestry has primarily been taking place in rural areas, but many of the tools developed are relevant to UPF as well. Close links with these and other existing initiatives will help in promoting UPF for sustainable urban development.

Key to the success of UPF as development tool is enhanced cooperation between developed and developing nations. Experience has shown that not only developing countries will benefit from the cooperation. The Western world can benefit from the extensive experien ces with social and community forestry in the developing world, as well from integrative approaches that deliver social, environmental, and economic benefits to all segments of society.

\section{LITERATURE CITED}

Anthon, S., and B.J. Thorsen. 2001. Værdisætning af statslig skovrejsning. En husprisanalyse. (Valuation of Afforestation by the State. A House Price Analysis). Skov \& Landskab, Danish Forest and Landscape Research Institute, Hoersholm. 57 pp (in Danish).

Burch, W.R., and J.M. Grove. 1993. People, trees and participation in the urban frontier. Unasylva 44(173):19-27.
Carter, E.J. 1994. The Potential of Urban Forestry in Developing Countries: A Concept Paper. Food and Agriculture Organization, Rome, Italy. 90 pp.

Chin, W.Y., and R. Corlett. 1963. The City and the Forest: Plant Life in Urban Singapore. Singapore University Press, Singapore. 186 pp.

Dwyer, J.F., D.J. Nowak, M.H. Noble, and S.M. Sisinni. 2000. Connecting people with ecosystems in the 21st century: An assessment of our nation's urban forests. Gen. Tech. Rep. PNW-GTR-490. U.S. Department of Agriculture, Forest Service, Pacific Northwest Research Station, Portland, OR.

El Lakany, H. (Ed.). 1999. Urban and Peri-Urban Forestry: Case Studies in Developing Countries. Food and Agriculture Organization, Rome, Italy. 194 pp.

Food and Agriculture Organization (FAO). 1995. An Annotated Bibliography of Urban Forestry in Developing Countries. Food and Agriculture Organization, Rome, Italy. 100 pp.

_ 2002. Urban and Peri-Urban Forestry SubProgramme: Strategic Framework for the Biennium 2002-2003 and Mid Term 2002-2007. Part of Forestry Department Mid Term Plan 2002-2007. Forest Conservation, Research and Education Service, Food and Agriculture Organization, Rome, Italy. 44 pp.

Girardet, H. 1992. The GAIA Atlas of Cities: New Directions For Sustainable Urban Living. Anchor Books/ Doubleday, New York, NY. 192 pp.

Grahn, P., and U.A. Stigsdotter. 2003. Landscape Planning and Stress. Urban Forestry \& Urban Greening 1(3):1-18.

Grey, G.W., and F.J. Deneke. 1986. Urban Forestry. Wiley, New York, NY. 299 pp.

Harris, R.W., J.R. Clark, and N.P. Matheny. 1999. Arboriculture: Integrated Management of Landscape Trees, Shrubs, and Vines (3rd ed.). Prentice Hall, Englewood Cliffs, NJ. 687 pp.

Johnston, M. 1996. A brief history of urban forestry in the United States. Arboric. J. 20:257-278.

Kambou, S. 1992. Urban forests in the tropical context: The case of the Forêt Classée du Barrage de Ouagadougou, Burkina Faso, pp 48-51. In Hummel, J., and M. Parren (Eds.). Forests: A Growing Concern. Proceedings of the XIXth International Forestry Students Symposium, Wageningen, The Netherlands, 30 September-7 October 1991. Stichting International Forestry Students Symposium Nederland (with IUCN), Wageningen, The Netherlands.

Kollin, C. 2002. Building an urban forest "green data layer" as a tool for local action, pp 46-49. In Selikhovkin, A., C. Konijnendijk, and O. Shaitarova (Eds.). Urban Forest Greenbelts: Functions Under Pressure. Abstracts of the 
conference, 29-30 April 2002, St. Petersburg, Russia. St. Petersburg State Forest Technical Academy, St. Petersburg, Russia.

Konijnendijk, C.C. 1999. Urban Forestry in Europe: A Comparative Study of Concepts, Policies and Planning for Forest Conservation, Management and Development in and around Major European Cities. Ph.D dissertation. Research Notes No. 90. Faculty of Forestry, University of Joensuu. 182 pp.

Konijnendijk, C.C., and T.B. Randrup. 2002. Editorial. Urban Forestry \& Urban Greening 1(1):1-4.

Konijnendijk, C.C., F. Salbitano, R. Gustavsson, A. Van Herzele, B. Hunter, A. Jönsson, K.M. Mäkinen, A. Ode, A. Ottitsch, J. Ryan, A. Simson, L. Tyrväinen, and R. De Vreese. 2002. NeighbourWoods: good practice in urban woodland planning and design, pp 33. In Konijnendijk, C.C., and K. Hoyer (Eds.). Forestry Serving Urbanised Societies. IUFRO European Regional Conference, in collaboration with EFI, Copenhagen, Denmark, 27-30 August 2002. Abstract Book. Urban Forestry \& Urban Greening, Supplement (2002).

Krott, M., and K. Nilsson, K. (Eds.). 1998. Multiple-Use of Town Forests in International Comparison. Proceedings of the 1st European Forum on Urban Forestry, 5-7 May 1998, Wuppertal, Denmark. IUFRO Working Group S.6.14.00. 198 pp.

Kuchelmeister, G. 1998. Urban Forestry in the Asia-Pacific Region: Status and Prospects. APFSOS Working Paper No. 44. Food and Agriculture Organization, Rome, Italy. 66 pp.

Kuchelmeister, G., and S. Braatz. 1993. Urban Forestry Revisited. Unasylva 173(44):3-12.

Kuo, F.E. 2003. The role of arboriculture in a healthy social ecology. J. Arboric. 29(3):148-155.

Lu, Q., and Wang, S. 2003. Dust-sand storms in China: Disastrous effects and mitigation strategies, p 447. In Forests: Source of Life. Congress Proceedings, BForests for the Planet. XII World Forestry Congress, Québec City, Québec, 21-28 September 2003.

McPherson E.G., D. Nowak, G. Heisler, S. Grimmond, C. Souch, R. Grant, and R. Rowntree. 1997. Quantifying urban forest structure, function, and value: The Chicago urban forest climate project. Urban Ecosys. 1:49-61.

McPherson E.G., and J.R. Simpson. 1999. Carbon Dioxide Reductions Through Urban Forestry: Guidelines for Professional and Volunteer Tree Planters. General Technical Report PSW-171. USDA Forest Service, Pacific Southwest Research Station, Albany, CA. 237 pp.

Miller, R.W. 1997. Urban Forestry: Planning and Managing Urban Greenspaces (2nd ed.). Prentice Hall, Englewood Cliffs, NJ. 502 pp.

Nilsson, K., and C.C. Konijnendijk. 2002. COST Action E12 Urban Forests and Trees-Final Report. COST, Brussels, Belgium. 17 pp.
Nilsson, K., J. Schipperijn, and T. Tvedt. 2003. Groene omraader stimulerer baerekraftig byutvikling (Greenspaces stimulate sustainable urban development). Park \& anlegg 8:19-23 (in Norwegian).

Palijon, A.M. 2001. An analysis of green space management strategies in Metro Manila, pp 147-164. In Sievänen, T., C.C. Konijnendijk, L. Langler, and K. Nilsson (Eds.). Forest and Social Services: The Role of Research. Proceedings of IUFRO Research Groups 6.01, 6.11.04, and 6.14 sessions at the XXI IUFRO World Congress 2000, Kuala Lumpur, Malaysia. Finnish Forest Research Institute, Vantaa, Finland.

_ 2002. Urban Dorestry in Asia: State of the Art. Paper presented at the IUFRO European regional conference 'Forestry serving urbanised societies', 27-30 August 2002, Copenhagen.

Ponting, C. 1991. A Green History of the World. Penguin Books, London, England. 430 pp.

Population Division of the Department of Economic and Social Affairs of the United Nations Secretariat. 1998. World Urbanization Prospects: The 1999 Revision. www.un.org/esa/populations/wup1999/wup99.htm (accessed 7/16/04).

Seeland, K. In press. Urban forestry in India and Nepal. In Konijnendijk, C.C., J. Schipperijn, and K. Nilsson (Eds.). COST Action E12 Urban Forests and TreesProceedings No. 2. Office for Official Publications of the European Communities, Brussels, Belgium.

Töpfer, K. 2001. The crucial importance of urban-rural linkages, pp 21-24. In Virchow, D., and J. von Braun (Eds.). Villages in the Future: Crops, Jobs and Livelihood. Springer, Berlin, Germany.

Tyrväinen, L. 1999. Monetary Valuation of Urban Forest Amenities in Finland. Academic dissertation. Research Papers 739. Finnish Forest Research Institute, Vantaa, Finland.

Unasylva. 1993. Special issue on urban and peri-urban forestry 44(173).

Webb, R. 1999. Urban and peri-urban forestry in SouthEast Asia: A comparative study of Hong Kong, Singapore and Kuala Lumpur, pp 30-74. In El Lakany, H. (Ed.). 1999. Urban and Peri-Urban Forestry: Case Studies in Developing Countries. Food and Agriculture Organization, Rome, Italy.

World Resources Institute (WRI). 2004. Earthtrends: The Environmental Informational Portal. World Resources Institute, Washington DC. earthtrends.wri.org (accessed $7 / 16 / 04)$.

Zwingle, E. 2002. Cities. National Geographic 2002(5):72-99. 
${ }^{1}$ Danish Centre for Forest, Landscape and Planning, KVL

Rolighedsvej 23

DK-1958 Frederikserg

Denmark

${ }^{2}$ Food and Agriculture Organization

Forestry Department

Forest Conservation, Research and Education Service (FORC)

Viale delle Terme di Caracalla

Rome, Italy

Résumé. Le développement urbain durable va exiger de fournir un environnement de vie sain et en santé avec des services de base pour tous. Une structure urbaine verte en santé et multifonctionnelle est l'un de ces services de base à pourvoir. La foresterie urbaine et périurbaine, en mettant l'emphase sur la domination de l'arbre dans les espaces verts urbains et périurbains, a une approche stratégique, intégrative, interdisciplinaire et participative. Son but est de soutenir le développement de multiples bénéfices provenant des arbres et des forêts au sein de l'environnement urbain. Récemment, la foresterie urbaine et périurbaine a fait l'objet d'un suivi large dans le monde, mais son potentiel pour les villes et les villages dans le développement des nations est encore non réalisé. La FAO des Nations Unies a développé une stratégie à moyen terme pour promouvoir et développer la foresterie urbaine et périurbaine comme composante du développement durable en milieu urbanisé avec une emphase sur le développement des nations. Cet article présente cette stratégie qui vise à augmenter la conscience, développer une manière de faire, générer de nouvelles technologies et connaissances, et améliorer le soutien envers la foresterie urbaine et périurbaine. Des exemples de programmes réussis de foresterie urbaine et périurbaine sont présentés à la fois pour les pays développés et pour ceux en voie de développement.

Zusammenfassung. Nachhaltige urbane Entwicklung erfordert eine gesunde und nachhaltige Umwelt mit einer guten Basisversorgung. Eine gesunde und multifunktionale urbane grüne Struktur ist eine Grundvoraussetzung. Urbane und peri-urbane Forstwirtschaft (UPF), die auf den baumdominierten Teil der urbanen und peri-urbanen Grünbereichen fokusiert, ist eine strategische, integrative, interdisziplinäre und partizipierender Ansatz. Das Ziel ist, nachhaltig multiple Vorteile von Wäldern und Bäumen zu entwickeln. Kürzlich hat der UPF breite Gefolgschaft auf der anderen Seite der Welt gefunden, aber sein Potential für Städte in unterentwickelten Länden ist nicht realisiert. Die FAO hat eine mittelfristige Strategie zur Promotion und Entwicklung von UPF als eine Komponente von nachhaltiger urbaner Entwicklung mit besonderem Augenmerk auf Entwicklungsländer entwickelt. Diese Studie führt diese Strategie ein, mit Hilfe wachsenden Bewusstseins, sich entwickelnder Kunst, neuer Technologie und Wissen und unterstützender nachhaltiger UPF. Beispiele erfolgreicher UPF-Programme aus entwickelten und sich noch entwickelnden Ländern sind hier präsentiert.

Resumen. El desarrollo urbano sustentable proporcionará un ambiente saludable para todos. Una estructura verde urbana saludable y multifuncional es uno de los servicios básicos a proporcionar. La dasonomía urbana y periurbana (UPF), se enfoca en la parte del espacio verde urbano y periurbano dominada por árboles, como una aproximación estratégica, integral, interdisciplinaria y participativa. Su objetivo es desarrollar sosteniblemente los beneficios múltiples de los bosques y árboles en ambientes urbanos. Recientemente, la UPF ha encontrado amplia aceptación en todo el mundo, pero su potencial para las ciudades y pueblos en países en desarrollo aún es incipiente. La Organización para la Alimentación de las Naciones Unidas (FAO) ha desarrollado una estrategia a mediano plazo para promover y desarrollar la UPF como un componente del desarrollo urbano sustentable, con énfasis en los países en desarrollo. Este reporte introduce esta estrategia, la cual ayuda a elevar la atención y el estado del arte, generando nueva tecnología y conocimiento, afianzando políticas e instituciones, diseminación de información y conocimiento y realzando el UPF sustentable. Se presentan ejemplos de programas UPF exitosos tanto en países desarrollados como en países en desarrollo. 